\title{
Seabirds: studies with parasitofauna and potential indicator for environmental anthropogenic impacts
}

\section{Aves marinhas: estudos com a parasitofauna e potencial indicador quanto à impactos antrópicos ambientais}

\author{
Andressa Maria Rorato Nascimento de Matos ${ }^{1}$; Camila Domit ${ }^{2}$; \\ Ana Paula Frederico Rodrigues Loureiro Bracarense ${ }^{3 *}$
}

\section{Highlights:}

Seabirds are exposed to multiple environmental and pathological stressors;

Seabirds are considered environmental sentinels due to their biologic characteristics;

Parasites are strategic components of ecosystems and have biological functions;

Parasitological studies might contribute to environmental conservation.

\begin{abstract}
The aim of this review was to present the main anthropogenic threats to seabirds, a taxonomic group described as environmental sentinels, and the dynamics between parasites and hosts and their relationship with the health of the marine ecosystem. Coastal marine environments support various anthropogenic activities, exposing seabirds to multiple and synergistic environmental changes. These activities are considered negative to the maintenance of several seabird species, such as exposure to constant aquatic contaminants and fishing. In addition, parasitic and infectious diseases (viral, bacterial, and fungal) may also play an important role in maintaining some seabird populations. Some pathogenic organisms have public health importance and/or may indicate environmental quality. Host-parasite interaction may be positive, negative, or absent depending on some environmental factors potentially associated with degradation, as well as intrinsic factors of host or parasite. In addition, investigating aspects of seabird mortality also contributes to the constant population monitoring and understanding of the interaction between animals, humans, and the environment. Thus, seabirds and their parasitofauna can provide important ecological and health information, including those related to environmental health, supporting strategies for reducing degradation and maintaining marine ecosystems.
\end{abstract}

Key words: Environment. Host-parasite interaction. Parasite. Threats.

\section{Resumo}

Esta revisão teve por objetivo apresentar as principais ameaças antrópicas às aves marinhas, grupo taxonômico descrito como sentinelas ambientais, e a dinâmica entre os parasitos e seus hospedeiros e sua relação com a saúde do ecossistema marinho. Ambientes marinhos-costeiros são áreas que

\footnotetext{
1 Discente de Doutorado, Programa de Pós-Graduação em Ciência Animal, Centro de Ciências Agrárias, Universidade Estadual de Londrina, UEL, Londrina, PR, Brasil. E-mail: andressarorato@gmail.com

2 Pesquisadora Dra ${ }^{\mathrm{a}}$, Laboratório de Ecologia e Conservação, Centro de Estudos do Mar, Universidade Federal do Paraná, UFPR, Pontal do Paraná, PR, Brasil. E-mail: cadomit@gmail.com

$3 \operatorname{Prof}^{\mathrm{a}} \mathrm{Dr}^{\mathrm{a}}$, Laboratório de Patologia Animal, Departamento de Medicina Veterinária Preventiva, Centro de Ciências Agrárias, UEL, Londrina, PR, Brasil. E-mail: anapaula@uel.br

* Author for correspondence
} 
sustentam diversas atividades antropogênicas, expondo as aves a múltiplas e sinérgicas modificações ambientais. Tais atividades são consideradas desfavoráveis à manutenção de diversas espécies de aves marinhas, como a exposição a constantes contaminantes aquáticos e a pesca. Além disso, enfermidades parasitárias e infecciosas (virais, bacterianas, fúngicas) podem também apresentar importante papel na manutenção das populações de alguns de aves marinhas. Alguns dos organismos patogênicos são de importância para a saúde pública e/ou podem indicar a qualidade ambiental. Em relação à interação hospedeiro-parasito, a mesma pode ser positiva, negativa ou nula dependendo de alguns fatores ambientais, potencialmente associados à degradação, e também a fatores intrínsecos do hospedeiro ou do parasito. Além disso, a investigação dos aspectos relativos à mortalidade de aves também contribui para o constante monitoramento populacional e para a compreensão da interação entre animais, homem e meio ambiente. Desta forma, ressalta-se que as aves marinhas e sua fauna parasitária podem fornecer importantes informações ecológicas e sanitárias, relacionadas inclusive com a saúde ambiental, auxiliando nas estratégias para redução da degradação e manutenção dos ecossistemas.

Palavras-chave: Ambiente. Ameaças. Interação parasito-hospedeiro. Parasito.

\section{Introduction}

Brazil covers a large portion of seabirds in the world (Vooren \& Brusque, 1999). Approximately 106 seabird species from 17 families are reported in the Brazilian territory, being the most abundant the procellarids (Procellariiformes order, Procellariidae family) and sternids (Charadriiformes order, family Sternidae) (Instituto Chico Mendes de Conservação da Biodiversidade [ICMBio], 2014). Regarding habitat, these species can be classified into coastal (found on beaches and nesting on coastal islands) or oceanic and pelagic (those that perform most of their activities and spend their time in open sea areas) (Sick, 1997). In addition, some species may have migratory habits because they have regular displacements between geographically separated areas for breeding and wintering, migrating when environmental conditions are unfavorable to their vital demands (ICMBio, 2016).

Seabirds, due to the diversity of habits and dependence of different environments for their vital activities, are exposed to multiple impacts caused mainly by anthropogenic activities, being more threatened when compared to other bird groups (Croxall et al., 2012). Among coastal and oceanic species, 20 are on the red list of endangered Brazilian species (ICMBio, 2018). Some of the main threats are the degradation, environmental pollution (oil and plastics), and incidental capture by fishing (Sick, 1997; Vooren \& Brusque 1999; Croxall et al., 2012). However, besides anthropogenic causes, diseases (fungal, bacterial, viral, and parasitic) are also major stressors for populations of seabirds and coastal birds, which are natural reservoirs of agents of public health importance, for instance, the avian influenza virus, Mycobacterium avium, avian malaria, among others (Serafini \& Lugarini, 2014). Parasitic diseases are among the potential diseases that affect birds, with relevance regarding health and ecological assessment, as they may indicate host immunosuppression levels and relationships of habitat and eating habits, respectively.

Anthropogenic and infectious agent stressors have a cumulative effect on organisms and can result in systemic and chronic problems for seabird populations (Serafini \& Lugarini, 2014). Despite numerous studies addressing the health and ecological parameters of seabirds and coastal birds, as well as the effects of anthropogenic impacts on different species and populations, few of them are joint assessments that address the context of animal vulnerability in the face of synergism between multiple sources of stress. Thus, in this context, this review first addresses the main anthropogenic activities that threaten the conservation of seabirds and some parasitic species reported in these animals (in Brazil and other countries) aiming to a better contextualization for the parasite-host interaction and reiterate its importance in studies with bird and marine ecosystem health. 


\section{Literature review}

The literature databases PubMed and Google Scholar were used to search for articles and reviews with the following keywords and their combinations: parasites, helminths, seabirds, threats, plastic, oil, chemical compounds, hostparasite, and environmental. Also, book chapters, documents, and publications from national and international governmental agencies related to the conservation and medicine of marine animals were used. The study site and studied species, both birds and parasites, were not restricted for the supplementary table. However, articles published from 2000 onwards were used as inclusion criteria.

\section{Main anthropogenic threats (fishing, chemical compounds, oil, and solid waste)}

Seabirds have historically been used as sentinels because they are easily observed, inhabit large coastal areas, have large populations, a long life, and especially because they occupy the top of the food chain (Burger \& Gochfeld, 2004). Sentinel animals are those used in regular and systematic studies to identify potential environmental changes (National Research Council [NRC], 1991). These changes may be due to the direct degradation of nesting and feeding sites (expansion of cities and ports and introduction of exotic species that prey on nests, chicks, eggs, and adults), pollution from industrial, urban, and agricultural wastewater, oil and port activities (plastics, petroleum, trace elements, pesticides, and drugs), and fishing (accidental and incidental captures, improper disposal of fishing supplies, and overexploitation of fishing resources) (Sick, 1997; Vooren \& Brusque, 1999; Tasker et al., 2000; Furness, 2003; Serafini \& Lugarini, 2014).

Among the many sources of aquatic and marine pollution, waste disposal from urban areas and industries, agrochemicals (herbicides, pesticides, and fungicides), persistent organic pollutants (POPs - polychlorinated biphenyl compounds and organochlorines), and pollutants derived from oil exploration and transportation stand out. Compounds, such as polychlorinated biphenyls (PCBs), agrochemicals, and trace elements, can be detected in the adipose tissue, liver, and muscles of birds.

Higher concentrations of POPs in the oil of the uropygial gland were observed in seabirds of the Northern Hemisphere when compared to those inhabiting the South. The species with the highest concentrations were Phalacrocorax aristotelis and $P$. capillatus, which feed on benthic fish, which may explain the results found (Yamashita et al., 2018). Moreover, a study conducted on the southeastern coast of Brazil found organochlorine compounds in birds with a low body condition, which can be aggravated in species that undergo long periods of migration (Colabuono, Taniguchi, $\&$ Montone, 2012). Thus, the concentration of these contaminants in marine animals may be related and vary according to the geographic distribution, migration, diet, and/or age of each evaluated species (Sick, 1997; Colabuono et al., 2012; Yamashita et al., 2018).

Experimental and observational studies have shown morphofunctional alterations in seabirds due to marine oil exploration, such as loss of buoyancy and thermoregulation (external contact with oil) (Figure 1A), macro and microscopic liver, renal, glandular, and gastrointestinal lesions (after oil ingestion), and embryonic mortality in eggs exposed during the incubation period (Leighton, 1986, 1993). A study conducted in Colombia found low concentrations of aromatic polycyclic hydrocarbons (organic pollutant from the oil industry) in sediment (7-41 ng g $\left.{ }^{-1}\right)$, water $\left(0.3-0.34 \mathrm{ng} \mathrm{mL}^{-1}\right)$, fishes (53.24 $\mathrm{ng} \mathrm{g}^{-1}$ ), and seabirds (Pelecanus occidentalis, Fregata magnificens, Phalacrocorax brasilianus, and Thalasseus maximus) (66 $\left.\mathrm{ng} \mathrm{g}^{-1}\right)$ when compared to polluted areas. However, these results show the chronic oil spill in the studied area, imposing risks to the ecosystem (Burgos-Núñez, Navarro-Frómeta, Marrugo-Negrete, EnamoradoMontes, \& Urango-Cárdenas, 2017). 

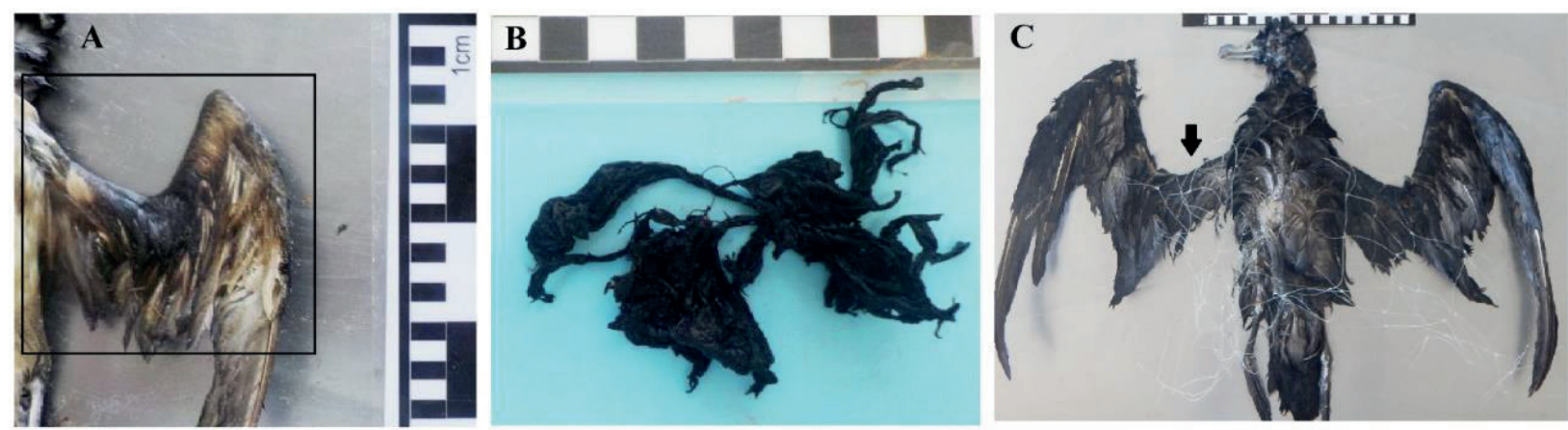

Source: Beach Monitoring Project - Santos Basin, Universidade Federal do Paraná, Pontal do Paraná, Paraná, Brazil. Figure 1. Macroscopic findings of anthropogenic interaction in stranded seabirds off the coast of the Paraná State. (A) Puffinus puffinus presenting blackish spot on left wing (demarcated area), suggestive of contact with oil. (B) Plastic residue found in the stomach of Procellaria aequinoctialis. (C) Procellaria aequinoctialis showing interaction with fishing net (arrow).

The importance of research on stranded birds should be emphasized to understand the effects of not only acute (during major spill accidents) but also chronic exposure caused by the sum of operational discharges, constant and small leaks, and/or spills during offshore drilling or transport operations (Camphuysen \& van Franeker, 1992).

Another type of ocean pollution occurs from plastic waste (Figure 1B), which has been a major global concern in recent decades. Awareness campaigns to generate information on their impacts, reduction of their use, and proper disposal have been carried out by the United Nations (Organização das Nações Unidas [ONU], 2019).

The presence of these residues in the gastrointestinal tract of seabirds in the Brazilian coast, with occasional obstructions, were reported in 70 stranded procellariforms (Rio Grande do Sul) after stormy days (Sick, 1997). As can be seen from that study, plastic fragments have been a source of anthropogenic impacts for over three decades. Plastic fragments were observed in the stomach of $64.54 \%$ out of a total of 110 stranded procellariiform off the south coast of São Paulo, being the southern giant petrel (Macronectes giganteus), black-browed albatross (Thalassarche melanophris), Manx shearwater (Puffinus puffinus), great shearwater (P. gravis), Cape petrel (Daption capense), and sooty shearwater ( $P$. griseus) the main affected species (Barbieri, 2009).

The growing concern about pollution from plastic products is due not only to severe cases of gastrointestinal obstruction in various species of marine and aquatic animals but also due to microplastic bioaccumulation (microscopic plastic products produced for different purposes or derived from environmental fragmentation of macroplastics). Microplastics cause toxicity along the trophic chain, a phenomenon known as biomagnification, and facilitate, as the macroplastics, the transport of small and/or microscopic species and other contaminants (metals, PCBs, etc.) to distant locations, positively or negatively interfering with the target ecosystem (Barnes, Galgani, Thompson, \& Barlaz, 2009; Wright, Thompson, \& Galloway, 2013; Wilcox, Van Sebille, \& Hardesty, 2015; Petry \& Benemann, 2017).

Any type of fishing activity conducted within the bird feeding area presents risks to unintentional fishing (Tasker et al., 2000). Besides direct mortality (capture by longlines, gillnets, or fish traps), there are also traumas and drownings caused by discarded fishing artifacts (ropes and nets) (Figure 1C) and changes in the availability of fish stocks, as they may be important sources of marine feed (Tasker et al., 2000; Furness 2003; Serafini \& Lugarini, 2014). 
There are reports that sixteen Brazilian seabird species interact with oceanic fishing activities. All of these species belong to the order Procellariiformes, the most representative in the number of species and specimens in Brazil. Birds of this order have a habit of feeding on weakened or dead prey found on the ocean surface or food debris preyed on by large fishes. Thus, they can supplement their diet with discards of fishing activities, ingesting even the baits that are in the hooks, especially the longline type. This impact was observed when the Procellariiformes population decline coincided with the period of increase in longline fisheries (Neves, Bugoni, \& Rossi-Wongtschowki, 2006). However, other types of fishing, such as using gillnets or traps, can also cause low to high negative population impact on various seabird species (Tasker et al., 2000).

Thus, it is possible to observe the importance of studies with populations affected by different anthropogenic activities by presenting the degree of interference in the population maintenance of related species, besides studies promoting actions and mitigation agreements for the conservation of marine fauna.

\section{Parasitic diseases}

Helminths reported in birds belong to three phyla: Platyhelminthes, Acanthocephala, and Nematoda (Amato \& Amato, 2010). The suborder Eucestoda (Platyhelminthes phylum, Cestoda order, Tetrabothriidae family) and the Digenea subclass (Platyhelminthes phylum, Trematoda class) have been described in most groups of seabirds (Hoberg, 1996, 2005).

Ascaridoid nematodes (Ascaridoidea superfamily, Anisakis and Contracaecum genera, mainly) commonly occur in the proventriculus and esophagus of piscivorous seabirds, while the genera Seuratia, Stegophorus, and Tetrameres are also found in the proventriculus and ventricle mainly of penguins, Procellariiformes, larids, and alcids (Hoberg, 2005). Low parasite-host specificity has been observed in parasitism by Seuratia shipley and Stegophorus diomedeae, as it occurs in various Procellariiformes, Charadriiformes, and Sphenisciformes (Schramm et al., 2018). In addition to helminths, seabirds may harbor hemoand histoparasite protists, ectoparasite arthropods, and, more rarely, pentastomids and leeches (Amato $\&$ Amato, 2010). Some studies have reported avian malaria, caused by hemoparasite Plasmodium spp. in Magellanic penguins (Spheniscus magellanicus) in Brazil (Bueno et al., 2010; Vanstreels et al., 2015), being a relevant disease mainly for individuals held in captivity, resulting in hemosiderosis, vasculitis, congestion, and edema in various organs (Vanstreels \& Parson, 2014).

A review study with surveys of the parasitofauna of penguins described 110 genera of metazoan parasites ( 85 with species identification), belonging to the Nematoda (31), Digenea (22), Cestoda (10), and Acanthocephala (7) groups. The penguin species with the highest richness of parasitofauna were the little penguin (Eudyptula minor) (30 species) and Magellanic penguin (S. magellanicus) (28 species) (Brandão, Moreira, \& Luque, 2014).

The species Renicola spp., a digenetic trematode often observed in seabird kidneys and ureters (Wright, 1954a) (Figure 2), has been reported in studies with Brazilian birds, such as in Charadriiformes (Larus spp., Sterna spp., and Thalasseus maximus) (Wright, 1954b; Freitas, 1955; Thatcher, 1993), Suliformes (Sula spp.) (Freitas, 1955; Thatcher, 1993), Magellanic penguins ( $S$. magellanicus) (Jerdy et al., 2016), and Manx shearwater (P. puffinus) (Mariani, 2016; Matos et al., 2019). In some species, the parasitic disease by renicolids may obstruct the tubular lumen or lead to more severe lesions such as nephritis, tubular hyperplasia, and fibrosis (Wright, 1954a; Munyer \& Holloway, 1990; Jerdy et al., 2016). 

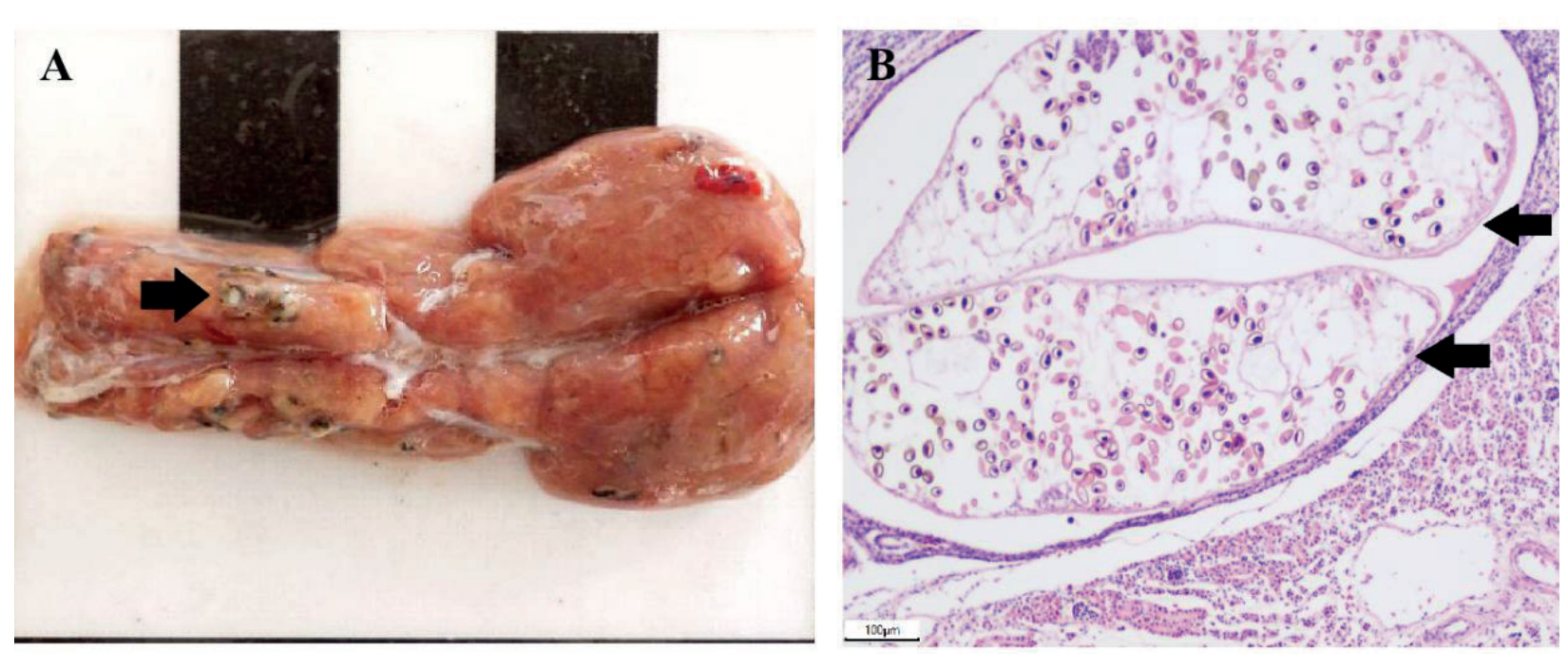

Source: (A) Beach Monitoring Project - Santos Basin, Universidade Federal do Paraná, Pontal do Paraná, Paraná, Brazil. (B) Laboratory of Animal Pathology, Universidade Estadual do Paraná, Londrina, Paraná, Brazil.

Figure 2. Renal parasitic disease in stranded Puffinus puffinus off the coast of the Paraná State. (A) Multifocal renicolid digenetic (arrow) in the renal parenchyma. (B) Photomicrograph of renicolid-parasitized renal tubule (arrows) (HE, bar $100 \mu \mathrm{m})$.

Supplementary Table S1 shows some studies on parasitic species found in Brazilian seabirds and from other localities published from 2000. Aquatic vertebrates usually have a richer parasitic community than terrestrial species (Poulin \& Morand, 2000), and helminths may inhabit various types of systems, such as digestive, pulmonary, and renal (Hoberg, 2005). However, most studies are related to helminths present in the gastrointestinal tract.

Associated with the identification of parasites, the understanding of their interaction with hosts and their role as biomarkers of environments altered by anthropogenic activities is sought (Lafferty \& Kuris, 1999). In addition, there are differences in helminth richness (species diversity) according to the marine environment in which the host is inserted, and birds that inhabit pelagic (oceanic) regions have less parasitic species variability when compared to those of neritic (on the continental shelf) or coastal environments. Moreover, parasitic richness also varies with the habitat of other hosts (intermediate) that comprise the parasite evolutionary cycle (Hoberg, 1996).
Mass mortality of seabirds is attributed to several causes, but studies to reveal the role of parasites in deaths are scarce (Rohde, 2005). In a study with Procellariiformes from the coast of Rio Grande do Sul, gastric lesions such as ulcers, inflammation, necrosis, and granulomas in the proventriculus were associated with parasitism by Seuratia spp. in southern giant petrel (M. giganteus) and northern giant petrel (M. halli) (Spotorno, Colabuono, Barquete, \& Vooren, 2005). However, the presence of parasites does not necessarily lead to tissue changes (Serafini \& Lugarini, 2014).

Mass mortality of seabirds is attributed to several causes. Other organisms, such as viruses, bacteria, and fungi, are commonly reported in seabirds. These organisms are reservoirs for some diseases and, associated with displacement capacity, wide geographical distribution, and coastal and oceanic habits, important elements in epidemiological studies with important agents for animal and human health (Hubálek, 2004; Komar \& Clark, 2006; Serafini \& Lugarini, 2014). However, studies to reveal the role of parasites in deaths are scarce (Rohde, 2005). In addition, infections are often associated with parasitosis, in which one makes it 
possible to install the other and maintain pathogens in the environment, and their potential risk to bird species depends on biotic (susceptible host species and vectors) and abiotic variables (e.g. temperature and humidity) (Serafini \& Lugarini, 2014).

There are still gaps in both detection of infectious and parasitic diseases in seabirds and understanding of their interaction and the degree of association with anthropogenic activities and environmental changes. However, from the marine biota monitoring project initiated in 2015 as a condition for pre-salt oil exploration, several research groups have had access to information and biological material of marine animals. The reports of this project from 2015 to 2018 on the beaches between Laguna, Santa Catarina State, and Ubatuba, São Paulo State, showed 48,245 beached marine animals, being 23,828 coastal, oceanic, and migratory birds (Petróleo Brasileiro S.A., 2019). Thus, it is clear the need for systematic studies with seabirds, as they are also sentinel animals of the health of the marine ecosystem.

The study of parasitofauna: ecological implications and association with environmental changes

A growing interest related to biodiversity was established from the beginning of the twentieth century, including parasitological studies (organisms usually not remembered and not visible, as they are in or on other organisms) (Amato \& Amato, 2010). Moreover, parasite species are poorly studied compared to other organisms, probably because they have complex biological cycles, usually small size, and often-confusing taxonomy (Gómez \& Nichols, 2013).

The different parasite species vary in number and type of hosts, i.e., some of them do not require intermediate hosts or vectors, and others parasitize only one definite host or several species. In addition, due to similar evolutionary pressures, flora and fauna of the same region are more closely related (Neves, 2009).
Many species of parasites use predator-prey interactions to complete their life cycle, being thus transmitted through the trophic chain. Therefore, the host only becomes infected within the endemic area of the particular parasite, which must have the necessary conditions, such as temperature and salinity, and all host species required to complete their life cycle (Mackenzie, 2005; VidalMartínez, Pech, Sures, Purucker, \& Poulin, 2010; Lafferty, 2013). Migratory birds showed recently no relationship between parasitic richness and distance traveled in the migration. Helminth species richness increases according to a variable diet, without necessarily undergoing the effects of other ecological characteristics. Thus, migratory birds that exploit diverse habitats and diets may be more exposed to an equally diverse parasite community (Gutiérrez, Rakhimberdiev, Piersma, \& Thieltges, 2017).

Species-specific interaction between parasite and host may result from coevolution between individuals or as a result of immediate ecological phenomena (Poulin \& Morand, 2000). Coevolution occurs when two organisms mutually influence their evolutionary changes. An example occurs when a host generates resistance against a parasite, and it subsequently evolves in response to this defense. Thus, the selection becomes reciprocal, favoring a joint and balanced evolution between parasite and host (Penn, 2001).

Periods of stress can affect parasite distribution and abundance, even when there is parasite-host specificity. In addition, parasitism by exotic agents, i.e., when they infect new host species, can cause changes in organic systems (Eiras, 1994; Pedersen, Jones, Nunn, \& Altizer, 2007). An example occurs when sea otter feeds on crustaceans parasitized by acanthocephalans adapted to the gut of seabirds. The parasite punctures the intestinal mucosa instead of sticking it due to significant intestinal differences between both species, leading to peritonitis and hence, the death of the host (Thomas \& Cole, 1996). 
Most helminths found in seabirds are components of the common parasitofauna and cause the death of their hosts during severe infections (Galaktionov, 1996). A high virulence may be due to the growth and multiplication of a parasite (i.e., both metazoan organisms and viruses, bacteria, fungi, and protozoa), which uses energy resources, causes tissue damage, or produces toxins in its hosts. In addition, the increase in the degree of virulence may occur in response to changes in host resistance. Thus, a parasite may present more virulence when its host resistance becomes reduced or has an exacerbated response (Penn, 2001).

The host-parasite dynamics that occur in the natural environment can also be affected when the introduction of domestic animals occurs during the colonization of new areas. New species may infect domestic and/or wild animals. However, the impacts of these changes are poorly documented because the effects are lower compared to other interferences in the wildlife conservation (e.g., viral/bacterial diseases, chemical compounds, solid waste, and fishing, among others) (Weinstein \& Lafferty, 2015).

Parasitism responses to environmental stressors may be (1) the increased degree of parasitism due to increased susceptibility of the definitive host and/or due to increased abundance of intermediate hosts or vectors; (2) the reduced parasitism if infected hosts suffer high mortality and/or due to reduced abundance of intermediate hosts or vectors; (3) the entry of new diseases to susceptible native populations from the introduction of exotic individuals (Lafferty \& Kuris, 1999).

Some parasite species from degraded environments are more generalist, parasitizing hosts with higher abundance, or have opportunistic behavior when parasitizing immunologically weakened hosts (Lafferty, 2013). Moreover, the reduced number of hosts in degraded habitats also reduces parasitic transmissions, mainly those with density-dependent transmission (Wood, Lafferty, \& Micheli, 2010).
Marine pollutants can have a positive, negative, or null effect on the physiological and/or numerical responses of some parasite species (Sures, 2008). Also, contrary to what might be believed, parasites can disappear before their hosts (Lafferty, 2013). In some cases, parasites may be more sensitive to pollutants when compared to their hosts, with effects varying according to the parasite species and between developmental stages (larval or adult stages) (Sures, 2004). However, in other cases, parasites contribute to bird mortality, as in high infections observed in common shag (Phalacrocorax aristotelis) when there is contamination with xenobiotics, such as oil, and/or synergistic effects caused by other bioaggressors (Abollo, Gestal, \& Pascual, 2001).

Birds that ingest petroleum (crude oil) after spillage may have reduced gastroenteric parasite load due to potential anthelmintic effects, mainly those parasite species that do not remain attached to the mucosa and/or due to the starvation period before death in these cases (Thieltges, Hussel, \& Baekgaard, 2006). The contact with crude oil reduces parasitism by digenetics and acanthocephalans but facilitates the increase of ciliates and monogenoids (Khan, 1987; Lafferty, 1997).

Chemical compounds and trace elements also have negative effects because they can function as anthelmintic substances (Lafferty, 1997). The average cadmium concentration in the larval stages of the acanthocephalan Pomphorhynchus laevis was approximately $1.8 \times 10^{2}$ times lower than that found in the adult parasite. In addition, lead and cadmium concentrations in adult acanthocephalans were 2.7 $\times 10^{3}$ and $4.0 \times 10^{2}$ times higher, respectively, than the concentration in muscle in host fish species, and $1.110^{4}$ and $2.710^{4}$ times higher, respectively, than that found in water (Sures \& Taraschewski, 1995; Sures, Taraschewski, \& Jackwerth, 1994). These studies show that the accumulation of trace elements occurs not only within the trophic chain but also during the stages of parasite development from marine pollution. 
Thus, an important aspect in the study of marine parasites is that these organisms can be used as biomarkers, especially those related to commercially used fish species (Mackenzie, 2005). Biomarkers reflect impacts by responding to environmental changes by changing their physiology, chemical composition, and/or behavior (Sures, 2004; VidalMartínez et al., 2010).

\section{Final considerations}

Researches and reviews often highlight the variety of responses that the host-parasite interaction offers to species conservation. There is also variation in responses according to the involved species and the environment in which they are inserted.

Because they are sentinel animals, seabirds present a vast universe for ecological and epidemiological studies. Moreover, parasites are strategic components of ecosystems and play important roles in being part of the evolutionary cycle of many, if not all, terrestrial and marine invertebrate and vertebrate species.

Negative effects of this interaction considering a limited understanding of population regulations and dynamics can occur for both parasite species and their intermediate and definitive hosts. Among others, these effects can be a reduction in parasite or host abundance, physiological and behavioral changes of both, or the generation of tissue damage to the hosts. Regardless of the effect, the consequences may be relevant to the ecosystem in which the species are inserted.

The breakdown of the parasite-host interaction equilibrium may occur due to several reasons, but there are growing and constant facilitation via human actions, such as environmental pollution and degradation and the introduction of exotic species.

Some studies are related to species with relevance in animal and human health, i.e., species that generate clinical conditions, economic losses, and public health challenges, while others present results aimed at an understanding of the parasitehost interaction and the way the parasite acts on populations (null, positive, or negative effect). Three components are understood to interact constantly in the single health context: host, infectious/parasite agent, and environment. When imbalances occur in the interaction of one or more of these components, the likelihood of negative results increases. Thus, there is a growing interest in interdisciplinarity so that in addition to identifying parasitic agents, they can be associated with other important components, including the environment.

\section{Acknowledgments}

This review is part of the Master's thesis of Matos, A. M. R. N. We thank CNPq for the financial assistance in granting the Master's scholarship, the Graduate Program in Animal Science, and the Santos Basin Beaches Monitoring Project, an environmental condition of the IBAMA to Petrobras and linked to the Universidade do Vale do Itajaí, and the Universidade Federal do Paraná for their support.

\section{References}

Abollo, E., Gestal, C., \& Pascual, S. (2001). Anisakid infection in the European shag Phalacrocorax aristotelis aristotelis. Journal of Helminthology, 75(3), 209-214. doi: 10.1079/JOH200051

Amato, J. F. R., \& Amato, S. B. (2010). Técnicas gerais para coleta e preparação de helmintos endoparasitos de aves. In S. Von Matter, F. C. Straube, V. de Queiroz Piacentini, I. A. Accordi, \& J. J. F. Cândido (Eds.), Ornitologia e conservação: ciência aplicada, técnicas de pesquisa e levantamento (pp. 369-393). Rio de Janeiro, RJ: Technical Books.

Barbieri, E. (2009). Occurrence of plastic particles in procellariiforms, south of Sao Paulo State (Brazil). Brazilian Archives of Biology and Technology, 52(2), 341-348. doi: 10.1590/S1516-89132009000200011

Barnes, D. K., Galgani, F., Thompson, R. C., \& Barlaz, M. (2009). Accumulation and fragmentation of plastic debris in global environments. Philosophical Transactions of the Royal Society of London B: 
Biological Sciences, 364(1526), 1985-1998. doi: 10.1098/rstb.2008.0205

Brandão, M. L., Moreira, J., \& Luque, J. L. (2014). Checklist of Platyhelminthes, Acanthocephala, Nematoda and Arthropoda parasitizing penguins of the world. Check List, 10(3), 562-573. doi: 10.1007/ s11230-013-9410-2

Bueno, M. G., Lopez, R. P. G., Menezes, R. M. T. de, Jesus Costa-Nascimento, M. de, Castro Lima, G. F. M. de, Sousa Araújo, R. A. de,... Kirchgatter, K. (2010). Identification of Plasmodium relictum causing mortality in penguins (Spheniscus magellanicus) from São Paulo Zoo, Brazil. Veterinary Parasitology, 173(1-2), 123-127. doi: 10.1016/j.vetpar.2010.06.026

Burger, J., \& Gochfeld, M. (2004). Marine birds as sentinels of environmental pollution. Ecohealth, 1(3), 263-274. doi: 10.1007/s10393-004-0096-4

Burgos-Núñez, S., Navarro-Frómeta, A., MarrugoNegrete, J., Enamorado-Montes, G., \& UrangoCárdenas, I. (2017). Polycyclic aromatic hydrocarbons and heavy metals in the Cispata Bay, Colombia: A marine tropical ecosystem. Marine Pollution Bulletin, 120(1-2), 379-386. doi: 10.1016/j. marpolbul.2017.05.016

Camphuysen, C. J., \& Van Franeker, J. A. (1992). The value of beached bird surveys in monitoring marine oil pollution. Zeist: Technisch Rapport Vogelbescherming 10. Retrieved from https:// www.researchgate.net/profile/Jan_Van_Franeker/ publication/287490289 The value of beached bird surveys in monitoring marine oil pollution/ links/5a647d08a6fdccb61c55cbec/The-value-ofbeached-bird-surveys-in-monitoring-marine-oilpollution.pdf

Colabuono, F. I., Taniguchi, S., \& Montone, R. C. (2012). Organochlorine contaminants in albatrosses and petrels during migration in South Atlantic Ocean. Chemosphere, 6(7), 701-708. doi: 10.1016/j. chemosphere.2011.10.043

Eiras, J. C. (1994). Platelminta. In Elementos de Ictioparasitologia (pp. 147-169). Porto: Fundação Eng Antonio de Almeida.

Freitas, J. F. T. (1955). Sobre dois trematódeos parasitos de aves: Philophthalmus lachrymosus Braun, 1902 e Renicola mirandaribeiroi n. sp. Arquivos do Museu Nacional, 32(42), 585-610. Retrieved from http://www.museunacional.ufrj.br/publicacoes/wpcontent/arquivos/Arqs $\% 20 \mathrm{v} \% 2042-\mathrm{II} \% 20 \mathrm{p} \% 20$ 585-610\%20Tremat $\%$ c3\%b3deos\%20parasitos\%20 de\%20aves.pdf
Furness, R. W. (2003). Impacts of fisheries on seabird communities. Scientia Marina, 67(S2), 33-45. doi: 10.3989/scimar.2003.67s233

Galaktionov, K. V. (1996). Impact of seabird helminths on host populations and coastal ecosystems. Bulletin of the Scandinavian Society of Parasitology, 6(2), 50-64. Retrieved from http://sbsp.eu/images/PDF/ Bulletin_SBSP/Old/SSP_Bulletin_1996_Vol_6_ No_2.pdf $\bar{f}$ page $=60$

Gómez, A., \& Nichols, E. (2013). Neglected wild life: parasitic biodiversity as a conservation target. International Journal for Parasitology: Parasites and Wildlife, 2, 222-227. doi: 10.1016/j. ijppaw.2013.07.002

Gutiérrez, J. S., Rakhimberdiev, E., Piersma, T., \& Thieltges, D. W. (2017). Migration and parasitism: habitat use, not migration distance, influences helminth species richness in Charadriiform birds. Journal of Biogeography, 44(5), 1137-1147. doi: 10.1111/jbi. 12956

Hoberg, E. P. (1996). Faunal diversity among avian parasite assemblages: the interaction of history, ecology, and biogeography in marine systems. Bulletin of the Scandinavian Society for Parasitology, 6(2), 65-89. Retrieved from https://digitalcommons. unl.edu/parasitologyfacpubs/789/

Hoberg, E. P. (2005). Marine birds and their helminths parasites. In K. Rohde (Ed.), Marine Parasitology (pp. 414-425). Oxon: CABI Publishing.

Hubálek, Z. (2004). An annotated checklist of pathogenic microorganisms associated with migratory birds. Journal of Wildlife Diseases, 40(4), 639-659. doi: 10.7589/0090-3558-40.4.639

Instituto Chico Mendes de Conservação da Biodiversidade (2014). Aves marinhas e costeiras. Brasília: Author. Recuperado de http://www.icmbio.gov.br/portal/ faunabrasileira/estado-de-conservacao/3632-avesmarinhas-e-costeiras

Instituto Chico Mendes de Conservação da Biodiversidade. (2016). Relatório anual de rotas e áreas de concentração de aves migratórias no Brasil. Brasília: Author. Recuperado de http://www.icmbio. gov.br/portal/images/stories/DCOM_Miolo_Rotas Migrat $\%$ C3\%B3rias_2016_final.pdf

Instituto Chico Mendes de Conservação da Biodiversidade. (2018). Livro Vermelho da fauna brasileira ameaçada de extinção: volume III - aves. Brasília: Author. Recuperado de http://www.icmbio. gov.br/ portal/ component/content/article/10187 
Jerdy, H., Baldassin, P., Werneck, M. R., Bianchi, M., Ribeiro, R. B., \& Carvalho, E. C. Q. (2016). First report of kidney lesions due to Renicola sp. (Digenea: Trematoda) in free-living Magellanic Penguins (Spheniscus magellanicus Forster, 1781) found on the coast of Brazil. Journal of Parasitology, 102(6), 650-652. doi: 10.1645/16-29

Khan, R. A. (1987). Crude oil and parasites of fish. Parasitology Today, 3(4), 99-100. doi: 10.1016/01694758(87)90043-3

Komar, N., \& Clark, G. G. (2006). West Nile virus activity in Latin America and the Caribbean. Revista Panamericana de Salud Pública, 19(2), 112-117. doi: 10.1590/s1020-49892006000200006

Lafferty, K. D. (1997). Environmental parasitology: what can parasites tell us about human impacts on the environment? Parasitology Today, 13(7), 251-255. doi: 10.1016/S0169-4758(97)01072-7

Lafferty, K. D. (2013). Parasites in marine food webs. Bulletin of Marine Science, 89(1), 123-134. doi: 10.5343/bms.2011.1124

Lafferty, K. D., \& Kuris, A. M. (1999). How environmental stress affects the impacts of parasites. Limnology and Oceanography, 44(3), 925-931. doi: 10.5343/bms.2011.1124

Leighton, F. A. (1986). Clinical, gross, and histological findings in herring gulls and Atlantic puffins that ingested Prudhoe Bay crude oil. Veterinary Pathology, 23(3), 254-263. doi: 10.1177/030098588602300305

Leighton, F. A. (1993). The toxicity of petroleum oils to birds. Environmental Reviews, 1(2), 92-103. doi: 10.1139/a93-008

Mackenzie, K. (2005). Parasites as biological tags. In K. Rohde (Ed.), Marine Parasitology (pp. 351-355). Oxon: CABI Publishing.

Mariani, D. B. (2016). Causas de encalhes de aves marinhas no nordeste do Brasil. Dissertação de mestrado, Universidade Federal Rural de Pernambuco, Recife, PE, Brasil. Recuperado de http://ww2.pgvet.ufrpe.br/sites/ww2.prppg.ufrpe.br/ files/2016.dissertacao-daniela_bueno_mariani.pdf

Matos, A. M. R. N., Lavorente, F. L. P., Lorenzetti, E., Meira, M. R. C., Fo., Nóbrega, D. F., Chryssafidis, A. L.,... Bracarense, A. P. F. R. L. (2019). Molecular identification and histological aspects of Renicola sloanei (Digenea: Renicolidae) in Puffinus puffinus (Aves: Procellariiformes): a first record. Revista Brasileira de Parasitologia Veterinária, 28(3), 367375. doi: 10.1590/S1984-29612019025
Munyer, P. D., \& Holloway, H. L., Jr. (1990). Renicola williamsi n. sp. (Trematoda: Digenea: Renicolidae) from the south polar skua, Catharacta maccormiki. Transactions of the American Microscopical Society, 109(1), 98-102. doi: 10.2307/3226600

National Research Council (1991). Animals as sentinels of environmental health hazards. Washington, DC: The National Academy Press. Retrieved from https:// www.ncbi.nlm.nih.gov/books/NBK234944/

Neves, D. P. (2009). Parasitologia dinâmica. 3nd ed. São Paulo: Atheneu.

Neves, T., Bugoni, L., \& Rossi-Wongtschowski, C. L. D. B. (2006). Aves oceânicas e suas interações com a pesca na Região Sudeste-Sul do Brasil. Série Documentos Revizee: Score Sul. Recuperado de https://www.marinha.mil.br/secirm/sites/www. marinha.mil.br.secirm/files/documentos/revizee/ score-sul-5.pdf

Organização das Nações Unidas (2019). Our planet is drowning in plastic pollution. Retrieved from: https://www.unenvironment.org/interactive/beatplastic-pollution/

Pedersen, A. B., Jones, K. E., Nunn, C. L., \& Altizer, S. (2007). Infectious diseases and extinction risk in wild mammals. Conservation Biology, 21(5), 12691279. doi: 10.1111/j.1523-1739.2007.00776.x

Penn, D. J. (2001). Coevolution: host-parasite. Trends in Genetics, 8, 213-219. doi: 10.1038/npg.els.0001765

Petróleo Brasileiro S.A. (2019). Projeto de monitoramento de praias. Recuperado de https:// www. comunicabaciadesantos.com.br/programaambiental/projeto-de-monitoramento-de-praiaspmp.html

Petry, M. V., \& Benemann, V. R. (2017). Ingestion of marine debris by the White-chinned Petrel (Procellaria aequinoctialis): is it increasing over time off southern Brazil? Marine Pollution Bulletin, 117(1-2), 131-135. doi: 10.1016/j. marpolbul.2017.01.073

Poulin, R., \& Morand, S. (2000). The diversity of parasites. The Quarterly Review of Biology, 75(3), 277-293. doi: 10.1086/393500

Rohde, K. (2005). Economic and environmental importance. In Rohde, K (Ed.), Marine parasitology (pp.76-87). Oxon: CABI Publishing.

Schramm, C. C., Mascarenhas, C. S., Gastal, S. B., Scheer, S., Müller, G., \& Robaldo, R. B. (2018). Acuariidae (Nematoda) in Procellariiformes (Aves) on the southern coast of Rio Grande do Sul, Brazil. 
Revista Brasileira de Parasitologia Veterinária, 27(1), 7-11. doi: 10.1590/s1984-29612017073

Serafini, P. P., \& Lugarini, C. (2014). Procellariiformes e outras aves de ambientes marinhos (albatroz, petrel, fragata, atobá, biguá, gaivota). In Z. S. Cubas, J. C. R. Silva, \& J. L. Catão-Dias (Eds.), Tratado de animais selvagens-medicina veterinária ( $2 \mathrm{a}$ ed., pp. 470-494). São Paulo: Editora Roca.

Sick, H. (1997). Ornitologia brasileira. Rio de Janeiro: Nova Fronteira.

Spotorno, B., Colabouno, F., Barquete, V., \& Vooren, C. (2005). Lesiones causadas por nemátodeos en el proventrículo de procellariiformes en el litoral sur del Brasil. Anais do Congreso Latinoamericano de Ciencias del Mar, Viña del Mar, Chile, 11.

Sures, B. (2004). Environmental parasitology: relevancy of parasites in monitoring environmental pollution. Trends in Parasitology, 20(4), 170-177. doi: 10.1016/j.pt.2004.01.014

Sures, B. (2008). Host-parasite interactions in polluted environments. Journal of Fish Biology, 73(9), 21332142. doi: 10.1111/j.1095-8649.2008.02057.x

Sures, B., \& Taraschewski, H. (1995). Cadmium concentrations in two adult acanthocephalans, Pomphorhynchus laevis and Acanthocephalus lucii, as compared with their fish hosts and cadmium and lead levels in larvae of $A$. lucii as compared with their crustacean host. Parasitology Research, 81(6), 494-497. doi: 10.1007/BF00931792

Sures, B., Taraschewski, H., \& Jackwerth, E. (1994). Lead accumulation in Pomphorhynchus laevis and its host. Journal of Parasitology, 80(3), 355-357. doi: $10.2307 / 3283403$

Tasker, M. L., Camphuysen, C. J., Cooper, J., Garthe, S., Montevecchi, W. A., \& Blaber, S. J. (2000). The impacts of fishing on marine birds. ICES Journal of Marine Science, 57(3), 531-547. doi: doi:10.1006/ jmsc. 2000.00714

Thatcher, V. E. (1993). Trematódeos neotropicais. Manaus, AM: INPA.

Thieltges, D. W., Hussel, B., \& Baekgaard, H. (2006). Endoparasites in common eiders Somateria mollissima from birds killed by an oil spill in the northern Wadden Sea. Journal of Sea Research, 55(4), 301-308. doi: 10.1016/j.seares.2005.12.001

Thomas, N. J., \& Cole, R. A. (1996). The risk of disease and threats to the wild population. Endangered Species Update, 13(2), 24-28. Retrieved from https:// pubs.er.usgs.gov/publication/1003893
Vanstreels, R. E. T., Silva, R. P., Fº, Kolesnikovas, C. K. M., Bhering, R. C. C., Ruoppolo, V., Epiphanio, S.,... Catão-Dias, J. L. (2015). Epidemiology and pathology of avian malaria in penguins undergoing rehabilitation in Brazil. Veterinary Research, 46(1), 30. doi: 10.1186/s13567-015-0160-9

Vanstreels, R. E., \& Parson, N. J. (2014). Malária aviária e outros hemosporídeos aviários. In Z. S. Cubas, J. C. R. Silva, \& J. L. Catão-Dias (Eds.), Tratado de animais selvagens-medicina veterinária (2a ed., pp. 1557-1574). São Paulo: Editora Roca.

Vidal-Martínez, V. M., Pech, D., Sures, B., Purucker, S. T., \& Poulin, R. (2010). Can parasites really reveal environmental impact? Trends in Parasitology, 26(1), 44-51. doi: 10.1016/j.pt.2009.11.001

Vooren, C. M., \& Brusque, L. F. (1999). As aves do ambiente costeiro do Brasil: biodiversidade e conservação. Rio Grande, RS: Fundação UFRG. Recuperado de http:// rodadas.anp.gov.br/arquivos/Round7/arquivos_r7/ PERFURACAO_R7/refere/Aves.pdf

Weinstein, S. B., \& Lafferty, K. D. (2015). How do humans affect wildlife nematodes? Trends in Parasitology, 31(5), 222-227. doi: 10.1016/j.pt.2015.01.005

Wilcox, C., Van Sebille, E., \& Hardesty, B. D. (2015). Threat of plastic pollution to seabirds is global, pervasive, and increasing. Proceedings of the National Academy of Sciences, 112(38), 1189911904. doi: 10.1073/pnas.1502108112

Wood, C. L., Lafferty, K. D., \& Micheli, F. (2010). Fishing out marine parasites? Impacts of fishing on rates of parasitism in the ocean. Ecology Letters, 13, 761-775. doi: 10.1111/j.1461-0248.2010.01467.x

Wright, C. A. (1954a). Trematodes of the genus Renicola from birds in British zoos, with descriptions of two new species. Proceedings of the Zoological Society of London, 124(1), 51-61. doi: 10.1111/j.10963642.1954.tb01477.x

Wright, C. A. (1954b). Trematodes of the genus Renicola from the kidneys of birds in Brazil. Revista Brasileira de Biologia, 14(1), 61-64.

Wright, S. L., Thompson, R. C., \& Galloway, T. S. (2013). The physical impacts of microplastics on marine organisms: a review. Environmental Pollution, 178, 483-492. doi: 10.1016/j.envpol.2013.02.031

Yamashita, R., Takada, H., Nakazawa, A., Takahashi, A., Ito, M., Yamamoto, T.,... Watanuk, Y. (2018). Global monitoring of persistent organic pollutants (POPs) using seabird preen gland oil. Archives of environmental contamination and toxicology, 75(4), 545-556. doi: 10.1007/s00244-018-0557-3 